\title{
Invited review: Management strategies capable of improving the reproductive performance of heat-stressed dairy cattle
}

\author{
V. M. Negrón-Pérez, D. W. Fausnacht, and M. L. Rhoads* \\ Department of Animal and Poultry Sciences, Virginia Polytechnic Institute and State University, Blacksburg 24061
}

\section{ABSTRACT}

Impaired fertility during periods of heat stress is the culmination of numerous physiological responses to heat stress, ranging from reduced estrus expression and altered follicular function to early embryonic death. Furthermore, heat-stressed dairy cattle exhibit a unique metabolic status that likely contributes to the observed reduction in fertility. An understanding of this unique physiological response can be used as a basis for improving cow management strategies, thereby reducing the negative effects of heat stress on reproduction. Potential opportunities for improving the management of dairy cattle during heat stress vary greatly and include feed additives, targeted cooling, genetic selection, embryo transfer and, potentially, crossbreeding. Previous studies indicate that dietary interventions such as melatonin and chromium supplementation could alleviate some of the detrimental effects of heat stress on fertility, and that factors involved in the methionine cycle would likely do the same. These supplements, particularly chromium, may improve reproductive performance during heat stress by alleviating insulinmediated damage to the follicle and its enclosed cumulus-oocyte complex. Beyond feed additives, some of the simplest, yet most effective strategies involve altering the timing of feeding and cooling to take advantage of comparatively low nighttime temperatures. Likewise, expansion of cooling systems to include breeding-age heifers and dry cows has significant benefits for dams and their offspring. More complicated but promising strategies involve the calculation of breeding values for thermotolerance, the identification of genomic markers for heat tolerance, and the development of beddingbased conductive cooling systems. Unfortunately, no single approach can completely rescue the fertility of lactating dairy cows during heat stress. That said, region-appropriate combinations of strategies can improve reproductive measures to reasonable levels.

Received April 1, 2019.

Accepted July 20, 2019.

*Corresponding author: rhoadsm@vt.edu
Key words: dairy cow, oocyte, fertility, reproduction, heat stress

\section{INTRODUCTION}

It has long been recognized that heat stress hinders the efficiency of animal production, causing severe financial losses to producers. Previous estimates place economic losses to the dairy industry at $\$ 897$ to $\$ 1,507$ million annually (for optimal and minimal heat abatement, respectively). In the harshest US climates (such as Florida and Texas), producers were estimated to lose $\$ 337$ to $\$ 383$ per cow per year as a result of environmental heat stress (St-Pierre et al., 2003). Because these estimates are more than a decade old, we can assume that actual losses in recent years have been much higher due to particularly severe summertime conditions and the ever-increasing costs of production. Further exacerbating the problem, patterns of population growth in more temperate climates, coupled with severe weather conditions, have contributed to an increase in the proportion of food-producing animals in hot climates (Roush, 1994; Hulme, 1997).

The detrimental effects of heat stress on dairy cattle are multifaceted and are measurable even during short bouts of high temperatures. Decreased milk production and reproductive efficiency are two of the primary consequences of heat stress that cause financial loss for dairy producers. Effects on milk production are immediate and are the most obvious consequence observed, because production can be easily monitored on a day-to-day basis. Decreased fertility as a result of heat stress is not as easy to quantify, because effects are both immediate and long lasting. Conception rates can decline 20 to $30 \%$ during the summer months (De Rensis and Scaramuzzi, 2003; Turk et al., 2015), resulting in more days open and more cows culled for reproductive failure (St-Pierre et al., 2003). Unfortunately, these losses are further compounded as carryover into the cooler months of the fall, where lingering effects of heat stress manifest as a delayed return to full fertility (approximately 2-mo delay). Reproductive responses to heat stress in dairy cattle are undeniably complex, 
and it is equally unlikely that a single solution to this problem exists.

Even though advanced heat-abatement strategies are employed in dairies, the efficacy of those strategies varies from region to region. In some regions with particularly severe heat and humidity, little to no heatrelated economic losses are recovered with traditional abatement strategies (Armstrong, 1994; St-Pierre et al., 2003). For decades, a "magic bullet" that alleviates the deleterious effects of heat stress has been the focus of significant interest. The tested approaches have generated variable degrees of success, but no single strategy has been capable of returning reproductive or lactational performance to thermoneutral levels. Nevertheless, even moderately effective strategies are worth considering as additions to heat stress management systems, and carefully planned combinations of these approaches may prove most beneficial. Before using any heat-abatement strategy on-farm, however, the cost-benefit ratio must be carefully evaluated. As research in this area progresses, it will inform the heat-abatement decisions made by producers through a deepened understanding of physiological adaptations to environmental conditions and their effect on fertility.

\section{REVIEW AND DISCUSSION}

\section{Brief Overview of the Heat-Stressed Dairy Cow}

Although it is a contributor, decreased DMI does not explain all of the production loss in heat-stressed dairy cattle. The metabolism of heat-stressed dairy cattle is truly unique and not yet completely understood. During periods of heat stress, DMI decreases and maintenance requirements increase as cattle attempt to dissipate excess heat load (West, 1999). In previous experiments, cows that were heat stressed in environmentally controlled chambers experienced a $41 \%$ decrease in milk yield, and pair-fed cows housed in thermoneutral conditions experienced only a $21 \%$ decrease in milk yield (Rhoads et al., 2009). Therefore, reduced nutrient intake accounts for only about $35 \%$ of decreased milk production during heat stress. The reasons for the production discrepancy between heat-stressed and pair-fed dairy cattle are currently under investigation and are most certainly linked to consequences of their unique metabolic state. Some of the physiological changes that have been observed in heat-stressed dairy cattle include altered circulating nonesterified fatty acids, IGF-I, total protein, albumin, urea nitrogen, methyl histidine, creatinine, immune function markers, and heat shock proteins (Rhoads et al., 2009; Wheelock et al., 2010; Lamp et al., 2015; Min et al., 2015, 2016; Kekana et al., 2018).
In addition to the previously mentioned changes in metabolites and proteins observed during heat stress, adipose responsiveness to adrenergic stimulus is blunted (Wheelock et al., 2010), indicating that cows experiencing a thermal load reprioritize fuel selection in favor of glucose. As a result, heat-stressed cows have lower circulating glucose concentrations (Rhoads et al., 2009; Wheelock et al., 2010; Alves et al., 2014) coupled with higher concentrations of insulin (Wheelock et al., 2010). Interestingly, the results of glucose and insulin tolerance tests indicate that heat-stressed cows remain insulin-responsive, in contrast to underfed dairy cows, which typically become insulin-insensitive (Wheelock et al., 2010). Similar results have been reported in rodents, pigs, and growing bulls (Hall et al., 1980; Torlińska et al., 1987; De Souza and Meier, 1993; O'Brien et al., 2010).

\section{Reproductive Challenges During Heat Stress}

Impaired fertility during periods of heat stress is the culmination of several consequences of heat stress, ranging from reduced estrus detection rates and altered follicular function to early embryonic death (Table 1; Collier et al., 1982a; Putney et al., 1988; Wolfenson et al., 1997; De Rensis and Scaramuzzi, 2003; West, 2003; Schüller et al., 2014; Polsky et al., 2017). All of these processes are important, but the effects on the ovarian follicle and its enclosed oocyte are particularly intriguing. Schüller et al. (2017) found that the ovarian follicle size was $0.1 \mathrm{~mm}$ less for each additional point on the temperature-humidity index on the day of estrus. This agrees with work reported by Wilson et al. (1998), who found that the second-wave dominant follicle was initially larger in heat-stressed dairy cattle, but that those follicles then grew more slowly over time, so that final diameter was detrimentally affected. The composition of the follicle fluid also differs during periods of heat stress (Alves et al., 2014), and many have reported differences in ovarian steroid concentrations between thermoneutral and heat-stressed animals (reviewed in Roth and Wolfenson, 2016).

Direct damage to the cumulus-oocyte complex has also been documented in cattle exposed to elevated ambient temperatures. Emerging research indicates that heat stress damages numerous components and functions of the bovine oocyte. Interestingly, a recent study in mice demonstrated that damage to the cytoplasm of the oocyte (ooplasm) has a greater effect on subsequent developmental competence than comparative heat-related effects on the nucleus (Wang et al., 2009). The relative location, morphology, and function of ooplasmic organelles (especially mitochondria) are altered by heat stress, and these changes are especially 
apparent in oocytes of Bos taurus origin. In contrast, the developmental competence of Bos indicus oocytes is retained after a heat stress insult (Silva et al., 2013), and this apparent thermal tolerance may be due, in large part, to the characteristics of the ooplasm. Interestingly, bovine oocytes collected during warm seasons are less susceptible to heat stress-induced damage (especially anomalous cytoplasmic maturation) than those collected during cool seasons (Maya-Soriano et al., 2013). Taken together, these results emphasize the importance of the ooplasm for fertility, particularly in heat-stressed cattle. Additional research is needed to define specific components and processes in the ooplasm that are detrimentally affected by thermal stress.

The problem of carryover effects from summer heat stress to fall fertility is also due to damage to the oocyte and amplifies the reproductive losses resulting from seasonal heat stress. Carryover refers to the period of approximately 2 mo of cooler autumn temperatures during which fertility remains low compared with the level of reproductive performance prevailing in winter. This is a direct result of the time it takes for damaged follicles to grow to ovulation and turnover, because approximately 40 to $50 \mathrm{~d}$ are needed for antral follicles to develop into large dominant follicles and ovulate (Lussier et al., 1987; Roth et al., 2001). If cows are inseminated just before ovulation of a heat-stress damaged follicle/oocyte, the probability of successful fertilization is reduced, and further development into a viable embryo is even less likely. Cooling dry cows near the end of gestation may reduce the detrimental effects of heat stress on the antral follicle containing the oocyte that is destined to ovulate 40 to $50 \mathrm{~d}$ later. This is particularly advantageous timing, because it coincides with the start of most breeding periods, and therefore could increase first-service conception rates.

The detrimental effects of heat stress on fertility are multiplied in production systems where bulls are still relied upon for some or all of the breeding. Although heat stress often does not affect libido, it is known to decrease sperm concentration, lower sperm motility, and increase the percentage of morphologically abnormal sperm in an ejaculate (Malama et al., 2017; SabésAlsina et al., 2017; Rahman et al., 2018). Perhaps more concerning is that the chromatin in the sperm is also detrimentally affected by heat stress (Rahman et al., 2011; Lucio et al., 2016), ultimately resulting in a further reduction of embryonic development (Lucio et al., 2016). These effects are long-lasting, because semen quality will not return to normal until the sperm from a new spermatic cycle have matured (approximately 2 mo in the bull). Periodic semen evaluation can provide producers with the information needed to make informed decisions about bull usage during the summer months.

\section{Cow Feeding During Heat Stress: What and When}

A relatively simple approach for improving cow comfort and production during heat stress is to take advantage of diurnal variations in ambient temperature and feeding behavior with the intent of reducing metabolic heat production at the hottest part of the day. One study demonstrated that rectal temperatures and respiration rates of heat-stressed dairy cattle could be reduced by simply changing the feeding time from morning to evening, or by feeding in the morning and evening (Calamari et al., 2013). Although no reproductive parameters were measured in this study, the observed reduction in rectal temperatures and respiration rates indicates that the change in feeding time reduced the effect of ambient temperature and, therefore, could improve fertility. Based on the results of a more recent study, however, caution is encouraged when considering night feeding, because it appears to reduce total-tract digestibility and overall feed intake (Niu and Harvatine, 2018). Unfortunately, neither of these studies was conducted in early-lactation cows, and both included relatively small numbers of cows housed in ambient, uncontrolled conditions. Therefore, this approach war-

Table 1. Negative effects of heat stress on dairy cow fertility

\begin{tabular}{l} 
Reproductive challenge \\
\hline Lower estrus detection rates \\
Reduced ovarian follicle size \\
Altered follicle fluid composition combined with abnormal ovarian \\
steroid concentrations \\
Altered location, morphology, and organelle function in oocytes \\
of Bos taurus origin \\
Carryover effects up to $50 \mathrm{~d}$ after exposure to heat stress \\
Decreased sperm concentration and motility, and increased \\
morphological abnormalities \\
Abnormal chromatin condensation in sperm \\
Early embryonic death
\end{tabular}

Reference

Collier et al. (1982a)

Wilson et al. (1998); Schüller et al. (2014); Schüller et al. (2017)

Alves et al. (2014); Roth and Wolfenson (2016)

Silva et al. (2013); Maya-Soriano et al. (2013)

Lussier et al. (1987); Roth et al. (2001)

Malama et al. (2017); Sabés-Alsina et al. (2017); Rahman et al. (2018)

Rahman et al. (2018); Lucio et al. (2016)

Putney et al. (1988); Ealy et al. (1993); Edwards and Hansen (1997) 
rants further investigation, with particular interest in whether this simple strategy could improve fertility.

In addition to considering changes to the way cows are fed, it is equally or even more important to consider what cows are fed during periods of thermal stress. Increasing the dietary concentrations of specific vitamins, minerals, antioxidants, and other nutrients has been shown to improve some aspects of the physiological response to heat stress (summarized in Table 2). Unfortunately, relatively few feeding studies investigate effects on reproductive outcomes. In those cases, effects on production can provide at least a preliminary indication as to whether the supplement in question might improve overall physiological status and thus, possibly fertility. The addition of saturated fatty acids, glutamine, chromium, and direct-fed microbials to the diets of lactating dairy cows have all proven to increase milk yield during periods of heat stress (Soltan, 2010; Wang et al., 2010; Boyd et al., 2011; Caroprese et al., 2013). Of these additives, only a couple have been tested as a mechanism for improving the fertility of heat-stressed dairy cattle: melatonin and chromium.

Melatonin. Melatonin has many properties, including potent antioxidant activity. This property is of particular interest in the fertility of lactating dairy cattle because heat stress is known to increase reactive oxygen species, particularly in the oocyte and early embryo (Cebrian-Serrano et al., 2013; Ortega et al., 2016; Payton et al., 2018). When administered as an implant at the time of dry-off, melatonin improved reproductive parameters under heat stress conditions in the subsequent lactation (Garcia-Ispierto et al., 2013). Cows that received melatonin had fewer days open and less first-trimester pregnancy loss, and they were less likely to be categorized as repeat breeders. Results from an in vitro experiment indicate that even though melatonin is an effective antioxidant and capable of significantly reducing reactive oxygen species in the zygote, this may not be the primary mechanism by which it improves fertility during heat stress (Ortega et al., 2016). One possible mechanism warranting further investigation is the ability of melatonin to alter uterine blood flow. In a recent study, dietary melatonin increased uterine blood flow by $25 \%$, and this was most pronounced in the ipsilateral uterine artery, where blood flow was increased by $32 \%$ (Brockus et al., 2016). Improved uterine blood flow could augment fertility during periods of heat stress by assisting with the delivery of hormones to and from the reproductive tract, many of which are reduced in concentration during heat stress.

Chromium. Chromium is a trace mineral with antioxidant properties, and is known to bolster the immune system, reduce body temperature, and improve insulin sensitivity (Moonsie-Shageer and Mowat, 1993; Zhang et al., 2014a; Leiva et al., 2017). When given to periparturient cows under heat stress conditions, chromium supplementation increased milk production and increased the percentage of cows that were pregnant within the first $28 \mathrm{~d}$ of the breeding period (Soltan, 2010). Dietary chromium is also thought to act as an anti-inflammatory agent in heat-stressed dairy cows (Zhang et al., 2014a). Improvements in the reproductive performance of chromium-supplemented cows in heat stress could result from these anti-inflammatory actions or from a reduction in circulating insulin concentrations. Circulating insulin concentrations were not reported in the heat stress-chromium study, but when insulin is elevated by overfeeding concentrate,

Table 2. Feed additives that improve the reproductive performance of heat-stressed dairy cows

\begin{tabular}{ll}
\hline Supplements and their benefits & Reference \\
\hline $\begin{array}{l}\text { Melatonin } \\
\text { Decreased days open and first-trimester pregnancy loss }\end{array}$ & $\begin{array}{l}\text { Garcia-Ispierto et al. (2013) } \\
\text { Brockus et al. (2016) }\end{array}$ \\
$\begin{array}{l}\text { Increased uterine blood flow } \\
\text { Chromium }\end{array}$ & $\begin{array}{l}\text { Moonsie-Shageer and Mowat (1993); Zhang et al. (2014a); Leiva et } \\
\text { al. (2017) } \\
\text { Improved immune system, and decreased body temperature and } \\
\text { hyperinsulinemia }\end{array}$ \\
$\begin{array}{l}\text { Increased pregnancy rates within the first 28 d of breeding period } \\
\text { Methionine }\end{array}$ & Nikkhah et al. (2013); Zhou et al. (2016); Batistel et al. (2017) \\
$\begin{array}{l}\text { Increased mammary gland health, improved ovarian function, } \\
\text { and shorter calving interval }\end{array}$ & $\begin{array}{l}\text { Girard et al. (1995); Girard and Matte (1998) } \\
\text { Folate }\end{array}$ \\
$\begin{array}{l}\text { Improved total milk production } \\
\text { Increased germ cell viability and embryo survival } \\
\text { (observed in fowl and mice) }\end{array}$ & \\
$\begin{array}{l}\text { Betaine } \\
\text { Promotion of growth-inducing hormones, such as IGF-I }\end{array}$ & $\begin{array}{l}\text { Senesi et al. (2013) } \\
\text { Restored growth rates in heat-stressed animals }\end{array}$ \\
$\begin{array}{l}\text { Increased follicle diameter and decreased ovulation time } \\
\text { Reduced complications due to calving and calving interval } \\
\text { to first service, and improved conception rates }\end{array}$ & $\begin{array}{l}\text { Cabezón et al. (2017) } \\
\text { Raheja et al. (2018) }\end{array}$ \\
\end{tabular}


the addition of chromium to the diet attenuates the rise in serum insulin concentrations (Leiva et al., 2017). This is important for the fertility of heat-stressed dairy cattle, because they characteristically enter a state of hyperinsulinemia. In some ways, hyperinsulinemia may enhance reproductive processes. For example, circulating insulin has a positive effect on postpartum follicular development (Gong et al., 2002; Garnsworthy et al., 2009). This seems to be overridden by its detrimental effects, however, the most pronounced of which is a reduction in oocyte quality. Diets designed to increase circulating insulin concentrations in cows and heifers decreased in vitro blastocyst development (Adamiak et al., 2005, 2006; Fouladi-Nashta et al., 2005). Furthermore, states of hyperinsulinemia are known to reduce oocyte quality in cattle, mice, and humans (Adamiak et al., 2005; Cardozo et al., 2011; Qiao and Feng, 2011; Ou et al., 2012). Thus, chromium's ability to modulate circulating insulin concentrations may act to rescue oocyte quality during periods of heat stress.

Methionine Cycle. Many enzymes related to the methionine methyl transfer pathway are highly expressed in bovine oocytes (Ikeda et al., 2010; Kwong et al., 2010). This pathway is important for DNA methylation and is a key point in the epigenetic regulation of developing embryos (Sinclair et al., 2007). Heat stress induces a variety of epigenetic modifications that can be passed from mother to offspring during embryogenesis (de Barros and Paula-Lopes, 2018) and fetal development (Skibiel et al., 2018). Disruptions of the methionine cycle increase the incidence of failed pregnancy, causing conditions such as neural tube defects and hyperhomocystinuria. As a result of the complexity and numerous enzymes involved in the methionine cycle and methyl transfer, several weak points can be improved through dietary supplementation. Methionine (Ikeda et al., 2010), betaine (Perez-Miguelsanz et al., 2017), and folate (van der Molen et al., 1996) all aid in the methionine cycle, acting as enzymatic substrates, co-substrates and co-factors that ultimately lead to improved methyl transfer (Stover, 2009; Kwong et al., 2010) and reduce homocysteine levels (van der Molen et al., 1996). Many of the treatments that improve methionine cycle functionality have already shown promise in improving animal reproductive performance and milk production, although they are not commonly linked mechanistically.

Methionine. Methionine supplementation has been evaluated extensively for its ability to ameliorate the adverse effects of heat stress on cattle. Because of metabolic adaptations to heat stress, amino acid oxidation increases, which results in a reduction in circulating amino acids, as well as reduced milk protein content (Rius et al., 2016; Guo et al., 2018). Therefore, restor- ing circulating amino acids is a logical nutritional strategy, particularly the amino acids most affected (such as methionine). Ruminant-protected methionine has been used as a feed additive with a variety of beneficial outcomes, such as increased feed intake, increased milk yield, increased milk fat and protein content, improved mammary cell health, improved ovary function, and shortened calving interval (Nikkhah et al., 2013; Zhou et al., 2016; Batistel et al., 2017). Methionine supplementation also improves liver function and reduces liver lymphocyte apoptosis during heat stress (Han et al., 2009). Adequate methionine is critical for maintaining DNA methylation and epigenetic regulation. Maternal methionine intake and circulating levels affect the epigenetics of their offspring (Sinclair et al., 2007), which can be critical in embryo survival during heat stress (Edwards and Hansen, 1997).

Folate. Folate is necessary as a co-enzyme for the transfer of methyl groups and the conversion of homocysteine back to methionine (van der Molen et al., 1996). This function makes folate a crucial component of embryo development (Kim et al., 2009; Ikeda et al., 2010). The cost of lactation pulls many micronutrients away from gestation, as demonstrated by the significant decrease in folate levels from mating to parturition (Girard et al., 1989). Pregnant or lactating cows may have trouble obtaining sufficient folate levels through dietary intake. Fortunately, folate supplementation can restore serum folate levels during gestation (Girard et al., 1989). Folate supplementation has also been shown to improve total milk production and decrease ash content (Girard et al., 1995; Girard and Matte, 1998). Heat stress may further increase the demand for folate in periparturient and lactating cows; this is indicated during heat stress in other species. Several studies have demonstrated the effectiveness of folic acid supplementation for restoring the egg-laying ability of heat-stressed fowl (Gursu et al., 2004; Akbarian et al., 2016). Heat stress-induced decreases in blastocyst cell number and increases in the production of reactive oxygen species in mouse embryos were ameliorated with folic acid supplementation (Koyama et al., 2012), as well as decreased incidence of neural tube defects (Shin and Shiota, 1999).

Betaine. Betaine is used as a growth-promoting supplement in many livestock species (Lawrence et al., 2002; Choe et al., 2010; Martins et al., 2012). A natural amino acid derivative, betaine promotes growthinducing hormones such as IGF-I (Senesi et al., 2013) when supplemented. However, betaine also plays a role in the methionine cycle, where it acts as a substrate for the enzyme betaine homocysteine S-methyltransferase (BHMT), a back-up to methionine synthase, which converts homocysteine back to methionine (Perez- 
Miguelsanz et al., 2017). Betaine has already proven beneficial in heat stress for its ability to restore growth rates in heat-stressed animals (Mendoza et al., 2017; Lan and Kim, 2018). There is also evidence that betaine supplementation improves lactation, as well as restoring follicle diameter and shortening ovulation time in heat-stressed sows (Cabezón et al., 2017). Although the effects of betaine supplementation may be questionable in cattle, there is evidence that it improves milk production in grazing dairy cattle in thermoneutral conditions (Hall et al., 2016; Dunshea et al., 2019). The issue of betaine and cattle is further complicated by heat stress, where supplementation was effective in protecting heat-stressed steers (DiGiacomo et al., 2014), but not effective in lactating, heat-stressed cows (Zhang et al., 2014b; Hall et al., 2016). The beneficial effects of betaine in heat-stressed cattle may be variable, but supplementation did reduce complications due to calving (retained placenta/metritis), shortened the interval from calving to first service, and improved conception rate in heat-stressed Karan Fries cows (Raheja et al., 2018). It is possible that the osmolar effects of betaine may be diminished during heat stress, at which point its effects on the methionine cycle become more critical.

Summary of Feed Supplementation. Both melatonin and chromium supplementation have proven to be effective strategies for improving the reproductive performance of heat-stressed dairy cattle, but the mechanism(s) by which they accomplish that task are unknown. Methionine, folate, and betaine likely improve performance by bolstering weak points in the methionine cycle. Unfortunately, none of these supplements can improve all aspects of reproductive efficiency to non-heat-stress levels. This is likely because of the myriad of physiological adaptations that affect wholebody metabolism of the dairy cow in addition to reproduction. It is apparent that no single standalone strategy will ameliorate the detrimental effects of heat stress on lactating cows. It is likely, however, that combinations of approaches (both nutritional and otherwise) can be combined to achieve reasonable reproductive performance during heat stress. The most effective strategies will vary from region to region as climates vary, and need to be chosen based on the resources and opportunities available to producers.

\section{Cow Management and Cooling}

Many studies reporting a negative effect of heat stress on subsequent fertility were published over 20 years ago, when the average milk yield of dairy cows was much less than it is today. Advances in the understanding and technology behind cow cooling have provided opportunities to reduce the negative effects of heat stress on production and reproduction. Cow cooling on dairy farms often involves the use of fans with or without soakers. This general commonality does not translate into a homogeneous cooling approach, because the size, power, and location of the fans, along with the soaking rate, can vary greatly. A comprehensive examination of the efficacy and cost-benefit ratio of these variable arrangements would be far too extensive to include in this review. Selected cooling approaches will be described here, with an emphasis on different ways to use cooling systems that are already in place and on systems for which reproductive outcomes have been reported.

One of the greatest opportunities to reduce the negative effects of heat stress during the pre- and postpartum periods is through strategic use of multiple cooling methods that have been proven to reduce rectal temperature and respiration rate. The approaches and recommendations for dairy cow cooling are numerous and varied, so factors such as regional weather patterns and the availability and cost of resources must be considered before implementing any cooling strategy. The cost-benefit ratio of any cooling system can be further improved by identifying and targeting locations in the dairy where the core body temperatures of cattle are most severe in magnitude, duration, or both.

Cooling systems and knowledge of proper cooling (when, where, and to what extent) to reduce heat stress has increased substantially. This is doubly important because cooling costs, such as electricity usage and system maintenance, represent a large investment for dairy producers; one that must prove to be worthwhile. Assuming that in a given region it is cost-prohibitive to run existing cooling systems $24 \mathrm{~h}$ per day, it is actually most effective to run the systems overnight rather than during the hottest part of the day. At first glance, this strategy is somewhat counterintuitive: it would seem to be extremely important to cool dairy cows when they are exposed to the highest ambient temperatures. However, a recent study demonstrated that the minimum daily body temperature is more indicative of milk production than the maximum temperature during periods of heat stress (Spiers et al., 2018). When cows were cooled overnight, their milk production decreased by $1.66 \%$, compared with a $6.81 \%$ reduction for cows cooled during the day. An important consideration for understanding this relationship is the fact that heat-stressed dairy cattle consume the vast majority of their daily feed intake during nighttime hours (Mallonée et al., 1985). As a result, nighttime cooling would encourage greater overnight feed intake. This further emphasizes the potential advantages of evening feeding discussed earlier. If dairy cows are more willing to consume their ration at night, especially while being cooled, it is essential that they have fresh feed avail- 
able for consumption. The reproductive performance of cattle being cooled and fed at night has not been reported. Based on the physiological information available, however, it is likely that pregnancy rates could also be improved with these strategies.

As previously mentioned, many cooling systems for dairy cattle use fans with or without soakers, taking advantage of evaporative cooling opportunities. The effectiveness of these systems is highly variable between and even within regions, depending on a myriad of factors, some of which are beyond the control of the producer. A different approach to cooling has gained interest in recent years and relies on conductive cooling. Conductive cooling involves direct contact between the cow and a cool surface, and is most commonly accomplished by providing cooled bedding for the cow to lie on (Gebremedhin et al., 2016). Although there are not yet any reports of the reproductive response to this cooling approach, it may prove to be a promising strategy for improving the fertility of dairy cattle during heat stress. This method of cooling has been shown to reduce rectal temperatures, reduce respiration rates, increase milk production, and increase DMI during heat stress (Ortiz et al., 2015; Perano et al., 2015). The demonstrated reduction in rectal temperature indicates the effectiveness of this strategy overall, and may be indicative of greater capacity for the reproductive tract to thermoregulate. This could prove to be most important for processes that involve a temperature gradient, such as ovulation and fertilization (Hunter et al., 2017; López-Gatius and Hunter, 2017, 2019).

Cooling Heifers and Dry Cows. It is important to emphasize that dry cows and breeding-age heifers should not be overlooked when designing cooling schemes. The summertime pregnancy rates of diary heifers can be improved even with short-term cooling ( 56.7 vs. $23.3 \%$ for maximally cooled vs. uncooled, respectively; Moghaddam et al., 2009). The cooling of gestating dry cows may be even more important, because heat stress experienced during this period affects both the dam and the calf (Collier et al., 1982a,b; Wolfenson et al., 1988; Avendaño-Reyes et al., 2010; Dahl et al., 2017). These effects are summarized in Table 3.

Because dry cows are not lactating, the detrimental consequences of heat stress during the dry period are not readily apparent (compared with reduced milk production in lactating cows), and some would incorrectly postulate that dry cows are not particularly susceptible to heat stress. However, cows in this production phase are already being subjected to the physiological stress-

Table 3. Cow management and potential positive effects on cow fertility after cooling

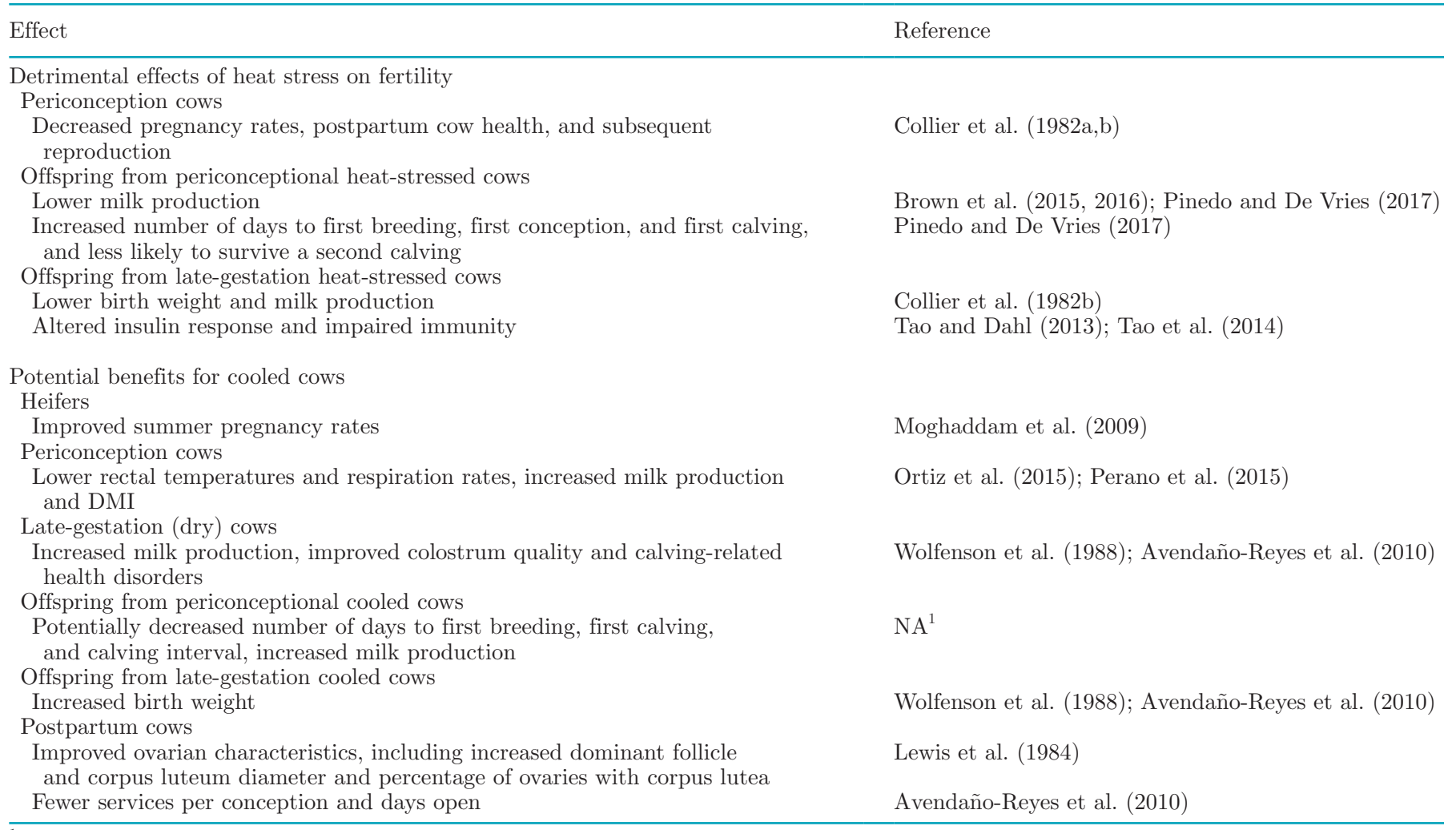

\footnotetext{
${ }^{1} \mathrm{NA}=$ not applicable.
} 
ors associated with late gestation as their bodies prepare for parturition as well as the next lactation, and the occurrence of heat stress adds further insult to this critical period. These physiological changes can increase cows' susceptibility to heat stress, having a detrimental influence on late pregnancy, postpartum cow health, milk production, and subsequent reproduction (Collier et al., 1982a,b). Collier et al. (1982b) reported that dairy cows experiencing heat stress during late gestation had calves with lower birth weights and produced less milk than cows that were not exposed to heat stress. These undesirable outcomes were associated with a reduction in circulating thyroxine, prolactin, growth hormone, and glucocorticoid concentrations. Subsequent research has shown that cooling dry cows may not only increase birth weights and milk production, but also improve colostrum quality and calving-related health disorders (Wolfenson et al., 1988; Avendaño-Reyes et al., 2010).

Compared with other aspects of the transition period, little fertility information is available for cows that were or were not cooled during the dry period. Postpartum cows provided with shade during the dry period exhibit more desirable ovarian characteristics, including greater ovarian volume, diameter of the largest follicle and corpus luteum, and percentage of ovaries with a corpus luteum compared to cows with no shade (Lewis et al., 1984). Unfortunately, these improved ovarian characteristics do not appear to result in meaningful improvements in reproductive benchmarks, because days to first ovulation and estrus, days open, and services per conception were unaltered by prepartum cooling with shade (Collier et al., 1982b; Lewis et al., 1984). In a subsequent study in which dry cows were more aggressively cooled, Avendaño-Reyes et al. (2010) concluded that using shades, fans, and water spray rather than shade alone decreased services per conception and days open, and increased milk yield during the postpartum period. Collectively, these studies emphasize the importance of minimizing heat stress during the dry period for the health and well-being of the cow.

As previously discussed, when cows are subjected to heat stress during the dry period, they display altered metabolism, immune function, and decreased milk production during the postpartum period (Collier et al., 1982b; do Amaral et al., 2009, 2011). These physiological changes affect not only the cow, but also the calf that is born from the heat-stressed pregnancy. Effects on the calves born following maternal late-gestation heat stress are equally detrimental, and include altered insulin response and impaired immunity (Tao and Dahl, 2013; Tao et al., 2014). Upon reaching adulthood, the milk production of the calves that were exposed to heat stress in utero during late gestation is also lower than their cooled counterparts (Dahl et al., 2017). The effects of late-gestation heat stress on dairy cows and their offspring have been comprehensively reviewed and warrant attention (Tao and Dahl, 2013; Dahl et al., 2017).

Periconceptional Heat Stress. Interestingly, when lactating dairy cattle are exposed to high ambient temperatures during the periconceptional period, the milk production of the resulting female offspring is also reduced. In studies examining tens of thousands of lactation records of primiparous and multiparous cows, those that had been conceived during the summer months produced less milk as an adult (Brown et al., 2015, 2016; Pinedo and De Vries, 2017). This effect was more pronounced in analyses of primiparous cows compared to multiparous cows (Brown et al., 2015, 2016). This difference could be due to inherent characteristics of their physiology, or the result of unequal loss and culling between heat-stress-conceived and thermoneutral-conceived cattle over multiple lactations. The latter notion is supported by the results of a recent study (Pinedo and De Vries, 2017) that showed that cows conceived in the summer were less likely to survive to a second calving. Furthermore, the reproductive performance (measured as days to first breeding, first conception, and first calving) of cows conceived in summer was consistently worse than that of cows conceived in winter (Pinedo and De Vries, 2017).

Although their potential for future milk production and reproductive performance is reduced by their prepartum exposure to heat stress, those heifer calves appear to possess one advantage: better thermotolerance. The evidence for this advantage was better capacity to sustain milk production during heat stress for those exposed during the periconceptional period (Brown et al., 2016), and higher skin temperature with a tendency for lower rectal temperature during heat stress for those exposed during late gestation (Ahmed et al., 2017). This advantage does not fully recover the income from lost production, but it does alleviate some concerns over whether periconceptional exposure should be a major consideration for the selection of replacement heifers.

Whether heat stress is experienced in the periconceptional period or during late gestation, it is detrimental to the future productivity of the resulting heifer calves. Both situations are problematic and difficult to avoid. Ideally, the timing of breeding and gestation would be planned so that it is unlikely for ambient temperatures to be high at either of these sensitive time points. In most cases, however, this is impossible or impractical, leaving heat abatement with maximal cooling efforts as the best option. It is important for producers to be 
aware of the detrimental effects of heat stress during the prepartum period on the resulting offspring (both periconceptional and late gestation), because it encourages close attention to the application of cooling when indicated, but does not warrant extreme measures such as culling or widespread crossbreeding based upon this association alone.

\section{Sire Selection}

It is widely accepted that Bos indicus cattle have a greater tolerance for elevated temperatures than Bos taurus animals. This difference may offer opportunities for improving the reproductive performance of dairy cattle during heat stress (Figure 1). In vitro studies over the past decade have investigated the influence of the sire and dam breed on the heat tolerance of bovine embryos (Block et al., 2002; Eberhardt et al., 2009; Satrapa et al., 2011). Preimplantation embryos of purebred Bos indicus (Nelore and Brahman), Bos taurus (Angus and Holstein) or crossbred origin were exposed to a 12 -h heat shock $\left(41^{\circ} \mathrm{C}\right.$ ) at the $>9$-cell (Block et al., 2002) or >16-cell stage (Eberhardt et al., 2009; Satrapa et al., 2011) and allowed to complete development to the blastocyst stage at the control temperature $\left(38.5^{\circ} \mathrm{C}\right)$. Overall, the pure Bos indicus embryos performed better than pure Bos taurus and crossbred embryos; crossbred embryos had similar development to pure Bos taurus embryos. The decrease in blastocyst development after heat shock was greatest when the oocytes were from Holstein cows. After exposure to heat shock, the reduction in blastocyst rate was at least 0 to $15 \%$ for pure Bos indicus embryos, 17 to $30 \%$ for crossbred (indicus dam $\times$ taurus sire) embryos, 30 to $40 \%$ for crossbred (taurus dam $\times$ indicus sire) embryos, and 45 to $75 \%$ for pure Bos taurus embryos (Block et al., 2002; Eberhardt et al., 2009; Satrapa et al., 2011). This suggests that although heat tolerance is influenced by breed, the oocyte breed has a greater influence than the sperm breed when conferring heat tolerance to the resulting embryo. At first glance, an understanding of the importance of the oocyte breed for thermotolerance does not seem very helpful, because most dairy cows have Bos taurus origins. Instead, however, this difference should be viewed as an opportunity for further research into the responsible mechanisms, which could lead to the discovery of new methods of improving the thermotolerance of our traditional dairy breeds.

Within a traditional dairy operation, however, it is usually quicker and easier to change the breed of the sire used in the breeding program than to change the breed of the dam. The effect of the sire and sire breed were further evaluated in South America over 2 sum- mers (Pegorer et al., 2007). Lactating Holstein cows were artificially inseminated with semen from bulls of Holstein (taurus) or Gyr (indicus) breeds, and evaluated for conception rates and pregnancy loss at 30 to $40 \mathrm{~d}$ and 60 to $80 \mathrm{~d}$ post-insemination. The resulting pregnancy rates at the end of the study were almost double for Holstein cows inseminated with Gyr semen (6.8-10.9\%) compared with Holstein cows inseminated with Holstein semen (3.9-6.1\%). Furthermore, pregnancy losses were lower for Holstein cows inseminated with Gyr semen (10-40\%) compared with Holstein cows inseminated with Holstein semen (18-38\%). It is also worth noting that $1 \mathrm{Gyr}$ bull in particular had fewer fetal losses than the other 3 Gyr bulls. This study indicated that the sire breed does indeed play a role in embryonic heat tolerance, and further indicated that individual sires within a breed differ in their ability to produce a successful pregnancy during heat stress (Pegorer et al., 2007). Even though the individual bull differences observed in this study were within the bulls from the Gyr breed, opportunities may exist to add a measurement of the heat tolerance of embryos to sire selection criteria in the dairy breeds.

Including Bos indicus sires in the summer breeding program for a dairy herd may be one approach for improving the overall heat tolerance of the herd. However, this approach has several disadvantages. Heifer calves born from a crossbreeding program using Bos indicus sires would not be suitable for raising as replacement heifers because of their lower potential for milk production, and in many regions, they might not be capable of tolerating the cold winter conditions. Selling all crossbred offspring for beef production is certainly an option, but would likely represent an economic loss compared with having those same offspring be purebred dairy calves or a crossbreed resulting from insemination with a Bos taurus beef sire. Even with some lost value of the offspring, crossbreeding with Bos indicus may increase the profitability of the dairy herd as a whole, because more cows would become pregnant during the summer months (i.e., fewer unsuccessful breedings and shortened calving interval), and more calves would be born from summertime inseminations.

\section{Selection for Thermotolerance and Genomics}

For many producers, crossbreeding with a Bos indicus sire is not possible or not desirable, emphasizing the importance of identifying sires within the Bos taurus dairy breeds that convey heat tolerance to the embryo and their adult female offspring. Likewise, the propagation of cows and cow families with superior reproductive performance during heat stress is equally 
important. In some regions and breeding systems, this could be accomplished by selecting animals that originated in and are acclimated to the weather conditions of that specific climate. Unfortunately, consistently and accurately identifying individuals that are acclimated to regional temperatures and that also have high genetic merit would be difficult, if not impossible. Similar advantages with more reliable outcomes could be accomplished through genomic predictions based on DNA markers present in heat-tolerant animals (Carabaño et al., 2019). Although it is a relatively new approach to improving heat tolerance, the heritability for rectal temperature has been reported as 0.17 in dairy cattle (Dikmen et al., 2012) and 0.19 in beef cattle (Riley et al., 2012). Genomic prediction for heat tolerance would allow young animals (bulls or heifers) to be selected based on the presence or absence of DNA markers that influence thermotolerance.
Genomic approaches are being developed for cattle in Australia by combining a decade of herd production data and Australian weather data (Nguyen et al. 2016). The efficacy of this selection process was tested by exposing animals predicted to be heat tolerant or heat-susceptible to a controlled heat challenge (Garner et al., 2016). As expected, heat-tolerant animals had less milk production loss and were able to regulate their body temperature better than the heat-susceptible animals. Although reproductive parameters were not reported, it is likely that the heat-tolerant animals are more likely to successfully establish a pregnancy when subjected to high ambient temperatures.

Although we have much to learn about the genetics of thermotolerance, one specific genetic trait that is known to improve body temperature regulation is the SLICK gene (Olson et al., 2003; Mariasegaram et al., 2007). Animals that carry this dominant gene pres-
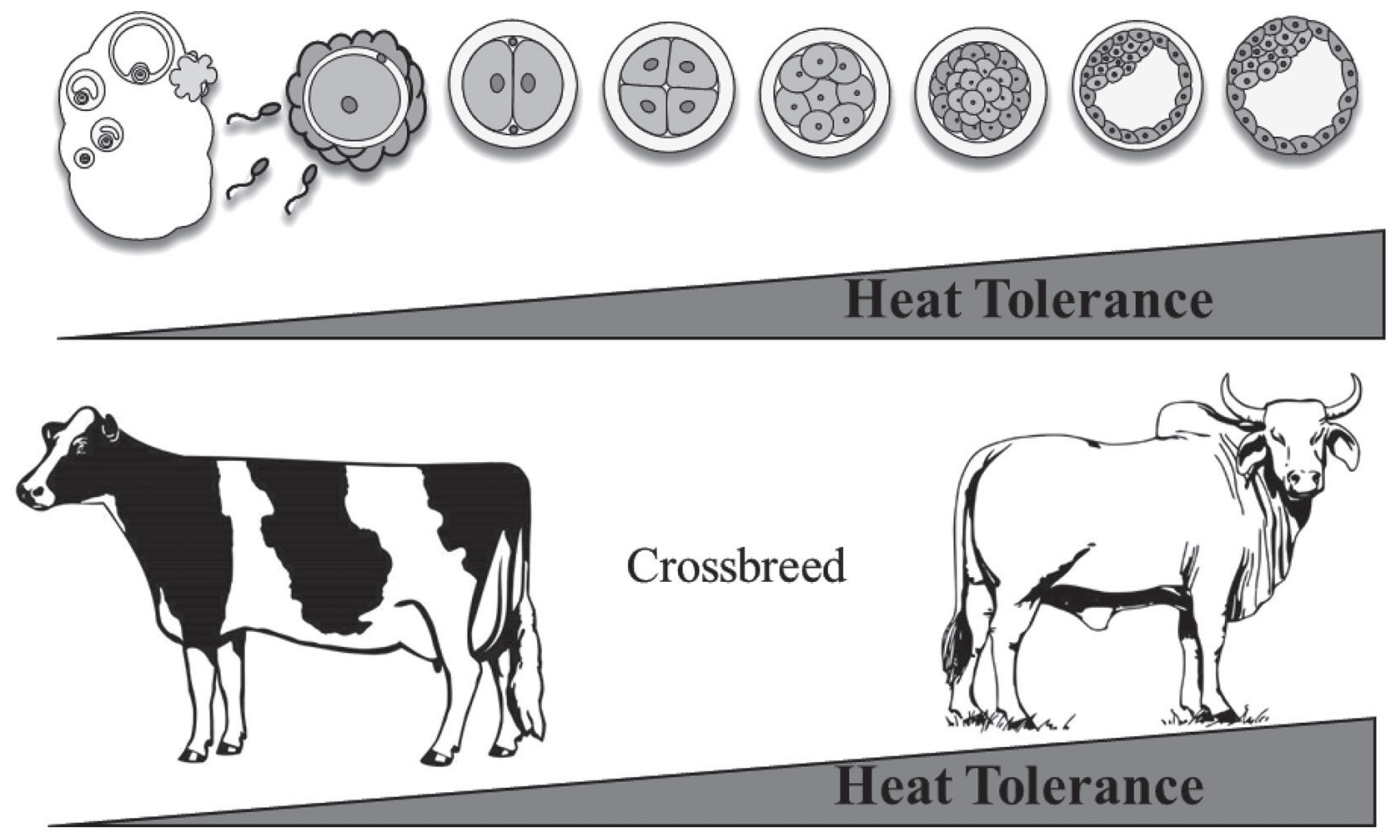

\section{Heat-adapted animals \\ Slick hair Holstein \\ $\uparrow$ Pregnancy per AI \\ $\uparrow$ Pregnancy per ET}

Figure 1. Developing follicles, oocytes, and sperm cells are highly susceptible to the detrimental effects of heat stress. Similarly, the preimplantation early embryo is susceptible to heat stress until the morula and blastocyst stage. Thus, embryo transfer (ET) can serve as an alternative to bypass the negative effects of heat stress on the early embryo. Further, Bos indicus breeds are known to be more heat tolerant than Bos taurus. Using semen from heat-adapted animals (such as the slick hair Holstein), Bos indicus, or crossbred sires could increase pregnancy rates during heat stress. 
ent a shorter hair phenotype, have fewer hair follicles, and have larger sweat glands that result in improved body thermoregulation and the ability to adapt to extreme heat conditions (Landaeta-Hernández et al., 2011). Previous research in tropical and subtropical areas has demonstrated that slick hair Holsteins can decrease their body temperature and increase sweating rates when exposed to high temperatures. One benefit recorded for the slick hair Holstein under heat stress conditions was increased milk production (Dikmen et al., 2014; Jimenez-Caban et al., 2015). Among other findings related to their reproductive ability, slick hair Holsteins have shorter calving intervals than wildtype Holsteins (Patiño Chaparro, 2016). Additional reproductive parameters are currently being studied to identify other advantages that the SLICK gene confers under heat stress conditions, and to determine how this trait can be incorporated into breeding selection strategies to alleviate the detrimental effects of heat stress (Figure 1).

\section{Estrous Synchronization and Ovarian Manipulation}

No matter how thorough and effective thermotolerance selection programs become, successful generation of pregnancies will always require that cows be inseminated at the proper time in their estrous cycles (the exception being embryo transfer, discussed below). Heat stress complicates this seemingly straightforward task by interfering with the expression and detection of estrus (Hansen and Arechiga, 1999). Producers can attempt to overcome this obstacle by increasing the time spent observing cows for signs of estrus, using any of the various available heat-detection aids, or both. In many instances, however, it is most advantageous to forgo estrus detection and proceed with a timed AI (TAI) program instead.

Successful implementation of a TAI program on-farm is not always an easy task, and selection of the protocol to be used should take into account the resources and challenges specific to each operation. Unfortunately, assessment of the efficacy of specific TAI protocols applied during heat stress is beyond the scope of this review. Given a choice, however, the protocols that rely heavily upon GnRH (such as Ovsynch and its numerous variations) are likely best suited for use in heat-stress conditions, because they assert significant control over the timing of ovulation (Pereira et al., 2013; Dirandeh 2014; De Rensis et al., 2015; Dirandeh et al., 2015). Even when using protocols that rely on detection of estrus, the administration of $\mathrm{GnRH}$ at the beginning of the breeding period (as a simple presynchronization) improves the reproductive performance of heat-stressed dairy cows (Voelz et al., 2016). Furthermore, it has been shown that GnRH treatment at the time of estrus improves circulating progesterone concentrations and embryo survival in heat-stressed dairy cattle (Ullah et al., 1996).

The merits of several types of estrous synchronization protocols have been thoroughly described in a review focused on seasonal heat stress by De Rensis et al. (2015). In reality, most if not all TAI programs have the potential to improve the reproductive performance of heat-stressed dairy cows, because they are designed to control the timing of the major events of the estrous cycle. However, it is critical that protocols be chosen based on the likelihood that they can be successfully implemented on a specific farm, because noncompliance is a major reason for failure of TAI programs.

Hormonal or physical manipulation of the follicles and oocytes on the ovary can also be used to overcome the long-lasting carryover effects of heat stress (reduced fertility for approximately 2 mo after heat stress; Roth et al., 2001; Friedman et al., 2014). One could assert that this is already being practiced on farms that use presynchronization protocols, because these protocols force follicular turnover, allowing small follicles to grow and reach dominance before insemination. In this way, presynchronization is helping to clear the ovary of damaged follicles and oocytes before insemination. A more extreme approach using transvaginal aspiration has proven to be effective, because multiple rounds of follicle ablation hastened the emergence of healthy follicles containing developmentally competent oocytes (Roth et al., 2001). Although this approach is effective, it would not be practical to attempt multiple rounds of transvaginal follicle aspiration for each cow needing to be inseminated in the autumn. This work does demonstrate, however, that the effects of heat stress carryover into the fall months and manifest themselves as a reduction in oocyte quality. Consequently, reproductive management strategies that promote follicle turnover will benefit cows recovering from summer heat stress.

\section{Embryo Transfer}

In addition to the gametes being negatively affected by heat stress (Lawrence et al., 2004; Roth and Hansen, 2004; Edwards et al., 2005; Roth and Hansen, 2005), the developing early embryo is also susceptible to elevated body temperature (Ealy et al., 1993; Edwards and Hansen, 1997). During heat stress, the quality of the embryo is lower (Sartori et al., 2002) and the females conceived in the summer are less productive upon reaching adulthood (Brown et al., 2015, 2016; Pinedo and De Vries, 2017). Even if the ovulated oocyte was not affected by 
heat stress, elevated body temperatures may be enough to cause embryonic damage. This is particularly true for the very early embryo ( $<6 \mathrm{~d}$ post-fertilization), and by the end of the first week post-fertilization (d 6-7), the bovine embryo is more heat tolerant (Figure 1; Ealy et al., 1993; Edwards and Hansen, 1997; Krininger et al., 2002; Sakatani et al., 2004).

The timing of greatest susceptibility to heat stress suggests that embryo transfer may be an effective strategy for overcoming early embryonic death due to elevated ambient temperatures. Embryos may be produced in vivo, recovered, and transferred to recipient cows or produced in vitro and then transferred. Embryos originating from either source may be transferred fresh or frozen-thawed and then transferred. Based on the studies that were previously discussed, transferred embryos would seem to be more likely to result in a successful pregnancy if transferred at the blastocyst stage (rather than late morula), because at this stage, the embryos have already gained some innate thermotolerance.

Unfortunately, the efficacy of embryo transfer for improving pregnancy rates during heat stress is hindered by the embryo freezing process (Sakatani, 2017), making fresh embryo transfer more successful even though it is less convenient. Studies have shown that cows receiving fresh embryo transfer are more likely to become pregnant than those that are artificially inseminated. In fact, summer pregnancy rates on d 42-60 postinsemination were 9 to 15 percentage points higher for fresh embryo transfer than for artificial insemination (Putney et al., 1989; Demetrio et al., 2007). In separate studies, fresh embryo transfer outperformed frozen embryo transfer by 9 to 12 percentage points (Ambrose et al., 1999; Al-Katanani et al., 2002).

The fact that the best pregnancy rates result from fresh embryos is somewhat unexpected, as this means that the oocytes used to produce those embryos would have come from cows that had also been heat stressed. This is in contrast to embryos that have been frozen and stored in liquid nitrogen before transfer, because they could have been produced using oocytes from cows in cool/cold ambient conditions. Regardless of how (in vivo or in vitro) the embryos are produced, however, only the best-quality embryos are selected for transfer, and this selection may explain the improved pregnancy rates. Furthermore, one must consider that in the case of embryos produced in vitro, those embryos are developing at the optimum temperature in an incubator during the most heat-susceptible developmental stages. Thus, where practical and available, the transfer of fresh (never frozen) embryos to heat-stressed dairy cattle is a viable opportunity to improve pregnancy rates during the summer months.

\section{CONCLUSIONS}

Dairy cattle that experience heat stress conditions enter into a unique physiological state that does not resemble the response to any other intrinsic or extrinsic challenge. The resulting detriment to fertility is multifaceted, because it alters all levels of reproductive function, ranging from estrus expression to follicular dynamics and early embryonic development. Strategies aimed at improving fertility (or at least lactational productivity) have sometimes proven beneficial, while at other times resulting in little to no improvement. Although the approaches to ameliorating the detrimental effects of heat stress have been broad and varied, none has succeeded in returning reproductive or lactational performance to thermoneutral levels. Some of the most successful have involved feed additives, targeted cooling, and embryo transfer. The inability of these strategies to fully rescue productivity does not preclude them from being beneficial on-farm. It is most likely that carefully planned combinations of approaches will produce the best results, allowing producers to achieve reasonable pregnancy rates during heat stress. Unfortunately, no one "best" approach has emerged that can be applied broadly across all regions and climates. The efficacy of strategies will vary from farm to farm, and approaches need to be chosen based on the circumstances, resources, and opportunities available to producers.

\section{ACKNOWLEDGMENTS}

Funding for this work was provided, in part, by the Virginia Agricultural Experiment Station and the Hatch Program of the National Institute of Food and Agriculture, U.S. Department of Agriculture.

\section{REFERENCES}

Adamiak, S. J., K. Mackie, R. G. Watt, R. Webb, and K. D. Sinclair. 2005. Impact of nutrition on oocyte quality: Cumulative effects of body composition and diet leading to hyperinsulinemia in cattle. Biol. Reprod. 73:918-926.

Adamiak, S. J., K. Powell, J. A. Rooke, R. Webb, and K. D. Sinclair. 2006. Body composition, dietary carbohydrates and fatty acids determine post-fertilisation development of bovine oocytes in vitro. Reproduction 131:247-258.

Ahmed, B. M. S., U. Younas, T. O. Asar, S. Dikmen, P. J. Hansen, and G. E. Dahl. 2017. Cows exposed to heat stress during fetal life exhibit improved thermal tolerance. J. Anim. Sci. 95:3497-3503.

Akbarian, A., J. Michiels, J. Degroote, M. Majdeddin, A. Golian, and S. De Smet. 2016. Association between heat stress and oxidative stress in poultry: Mitochondrial dysfunction and dietary interventions with phytochemicals. J. Anim. Sci. Biotechnol. 7:37.

Al-Katanani, Y. M., M. Drost, R. L. Monson, J. J. Rutledge, C. E. Krininger 3rd, J. Block, W. W. Thatcher, and P. J. Hanse. 2002. Pregnancy rates following timed embryo transfer with fresh or vitrified in vitro produced embryos in lactating dairy cows under heat stress conditions. Theriogenology 58:171-182. 
Alves, B. G., K. A. Alves, M. C. Martins, L. S. Braga, T. H. Silva, B. G. Alves, R. M. Santos, T. V. Silva, M. A. Viu, M. E. Beletti, J. O. Jacomini, and M. L. Gambarini. 2014. Metabolic profile of serum and follicular fluid from postpartum dairy cows during summer and winter. Reprod. Fertil. Dev. 26:866-874.

Ambrose, J. D., M. Drost, R. L. Monson, J. J. Rutledge, M. L. Leibfried-Rutledge, M. J. Thatcher, T. Kassa, M. Binelli, P. J. Hansen, P. J. Chenoweth, and W. W. Thatcher. 1999. Efficacy of timed embryo transfer with fresh and frozen in vitro produced embryos to increase pregnancy rates in heat-stressed dairy cattle. J. Dairy Sci. 82:2369-2376.

Armstrong, D. V. 1994. Heat stress interaction with shade and cooling. J. Dairy Sci. 77:2044-2050.

Avendaño-Reyes, L., J. W. Fuquay, R. B. Moore, Z. Liu, B. L. Clark, and C. Vierhout. 2010. Relationship between accumulated heat stress during the dry period, body condition score, and reproduction parameters of Holstein cows in tropical conditions. Trop. Anim. Health Prod. 42:265-273.

Batistel, F., J. M. Arroyo, A. Bellingeri, L. Wang, B. Saremi, C. Parys, E. Trevisi, F. C. Cardoso, and J. J. Loor. 2017. Ethyl-cellulose rumen-protected methionine enhances performance during the periparturient period and early lactation in Holstein dairy cows. J. Dairy Sci. 100:7455-7467.

Block, J., C. C. Chase Jr., and P. J. Hansen. 2002. Inheritance of resistance of bovine preimplantation embryos to heat shock: Relative importance of the maternal versus paternal contribution. Mol. Reprod. Dev. 63:32-37.

Boyd, J., J. W. West, and J. K. Bernard. 2011. Effects of the addition of direct-fed microbials and glycerol to the diet of lactating dairy cows on milk yield and apparent efficiency of yield. J. Dairy Sci. 94:4616-4622.

Brockus, K. E., C. G. Hart, C. L. Gilfeather, B. O. Fleming, and C. O. Lemley. 2016. Dietary melatonin alters uterine artery hemodynamics in pregnant Holstein heifers. Domest. Anim. Endocrinol. $55: 1-10$.

Brown, B. M., J. W. Stallings, J. S. Clay, and M. L. Rhoads. 2015. Periconceptional heat stress of holstein dams is associated with differences in daughter milk production and composition during multiple lactations. PLoS One 10:e0133574.

Brown, B. M., J. W. Stallings, J. S. Clay, and M. L. Rhoads. 2016. Periconceptional heat stress of holstein dams is associated with differences in daughter milk production during their first lactation. PLoS One 11:e0148234.

Cabezón, F. A., K. R. Stewart, A. P. Schinckel, and B. T. Richert. 2017. Effects of betaine and heat stress on lactation and postweaning reproductive performance of sows. Prof. Anim. Sci. 33:241-253.

Calamari, L., F. Petrera, L. Stefanini, and F. Abeni. 2013. Effects of different feeding time and frequency on metabolic conditions and milk production in heat-stressed dairy cows. Int. J. Biometeorol. 57:785-796.

Carabaño, M. J., M. Ramón, A. Menéndez-Buxadera, A. Molina, and C. Díaz. 2019. Selecting for heat tolerance. Anim. Front. 9:62-68.

Cardozo, E., M. E. Pavone, and J. E. Hirshfeld-Cytron. 2011. Metabolic syndrome and oocyte quality. Trends Endocrinol. Metab. 22:103-109.

Caroprese, M., M. Albenzio, R. Marino, A. Santillo, and A. Sevi. 2013. Dietary glutamine enhances immune responses of dairy cows under high ambient temperature. J. Dairy Sci. 96:3002-3011.

Cebrian-Serrano, A., I. Salvador, E. Raga, A. Dinnyes, and M. A. Silvestre. 2013. Beneficial effect of melatonin on blastocyst in vitro production from heat-stressed bovine oocytes. Reprod. Domest. Anim. 48:738-746.

Choe, H. S., H. L. Li, J. H. Park, C. W. Kang, and K. S. Ryu. 2010. Effects of dietary betaine on the secretion of insulin-like growth factor-I and insulin-like growth factor binding protein-1 and -3 in laying hens. Asian-Australas. J. Anim. Sci. 23:379-384.

Collier, R. J., D. K. Beede, W. W. Thatcher, L. A. Israel, and C. J. Wilcox. 1982a. Influences of environment and its modification on dairy animal health and production. J. Dairy Sci. 65:2213-2227.

Collier, R. J., S. G. Doelger, H. H. Head, W. W. Thatcher, and C. J. Wilcox. 1982b. Effects of heat stress during pregnancy on maternal hormone concentrations, calf birth weight and postpartum milk vield of Holstein cows. J. Anim. Sci. 54:309-319.

Dahl, G. E., S. Tao, and J. Laporta. 2017. Triennial Lactation Symposium/BOLFA: Late gestation heat stress of dairy cattle programs dam and daughter milk production. J. Anim. Sci. 95:5701-5710.

de Barros, F. R. O., and F. F. Paula-Lopes. 2018. Cellular and epigenetic changes induced by heat stress in bovine preimplantation embryos. Mol. Reprod. Dev. 85:810-820.

De Rensis, F., I. Garcia-Ispierto, and F. Lopez-Gatius. 2015. Seasonal heat stress: Clinical implications and hormone treatments for the fertility of dairy cows. Theriogenology 84:659-666.

De Rensis, F., and R. J. Scaramuzzi. 2003. Heat stress and seasonal effects on reproduction in the dairy cow-A review. Theriogenology 60:1139-1151.

De Souza, C. J., and A. H. Meier. 1993. Alterations in body fat stores and plasma insulin levels with daily intervals of heat exposure in Holtzman rats. Am. J. Physiol. 265:R1109-R1114.

Demetrio, D. G., R. M. Santos, C. G. Demetrio, and J. L. Vasconcelos. 2007. Factors affecting conception rates following artificial insemination or embryo transfer in lactating Holstein cows. J. Dairy Sci. 90:5073-5082.

DiGiacomo, K., R. D. Warner, B. J. Leury, J. B. Gaughan, and F. R. Dunshea. 2014. Dietary betaine supplementation has energy-sparing effects in feedlot cattle during summer, particularly in those without access to shade. Anim. Prod. Sci. 54:450-458.

Dikmen, S., J. B. Cole, D. J. Null, and P. J. Hansen. 2012. Heritability of rectal temperature and genetic correlations with production and reproduction traits in dairy cattle. J. Dairy Sci. 95:3401-3405.

Dikmen, S., F. A. Khan, H. J. Huson, T. S. Sonstegard, J. I. Moss, G. E. Dahl, and P. J. Hansen. 2014. The SLICK hair locus derived from Senepol cattle confers thermotolerance to intensively managed lactating Holstein cows. J. Dairy Sci. 97:5508-5520.

Dirandeh, E. 2014. Starting Ovsynch protocol on day 6 of first postpartum estrous cycle increased fertility in dairy cows by affecting ovarian response during heat stress. Anim. Reprod. Sci. 149:135140

Dirandeh, E., A. R. Roodbari, and M. G. Colazo. 2015. DoubleOvsynch, compared with presynch with or without GnRH, improves fertility in heat-stressed lactating dairy cows. Theriogenology 83:438-443.

do Amaral, B. C., E. E. Connor, S. Tao, J. Hayen, J. Bubolz, and G. E. Dahl. 2009. Heat-stress abatement during the dry period: Does cooling improve transition into lactation? J. Dairy Sci. 92:59885999 .

do Amaral, B. C., E. E. Connor, S. Tao, M. J. Haven, J. W. Bubolz, and G. E. Dahl. 2011. Heat stress abatement during the dry period influences metabolic gene expression and improves immune status in the transition period of dairy cows. J. Dairy Sci. 94:86-96.

Dunshea, F. R., K. Oluboyede, K. DiGiacomo, B. J. Leury, and J. J. Cottrell. 2019. Betaine improves milk yield in grazing dairy cows supplemented with concentrates at high temperatures. Animals (Basel) 9:57.

Ealy, A. D., M. Drost, and P. J. Hansen. 1993. Developmental changes in embryonic resistance to adverse effects of maternal heat stress in cows. J. Dairy Sci. 76:2899-2905.

Eberhardt, B. G., R. A. Satrapa, C. R. Capinzaiki, L. A. Trinca, and C. M. Barros. 2009. Influence of the breed of bull (Bos taurus indicus vs. Bos taurus taurus) and the breed of cow (Bos taurus indicus, Bos taurus taurus and crossbred) on the resistance of bovine embryos to heat. Anim. Reprod. Sci. 114:54-61.

Edwards, J. L., and P. J. Hansen. 1997. Differential responses of bovine oocytes and preimplantation embryos to heat shock. Mol. Reprod. Dev. 46:138-145.

Edwards, J. L., A. M. Saxton, J. L. Lawrence, R. R. Payton, and J. R. Dunlap. 2005. Exposure to a physiologically relevant elevated temperature hastens in vitro maturation in bovine oocytes. J. Dairy Sci. 88:4326-4333.

Fouladi-Nashta, A. A., C. G. Gutierrez, P. C. Garnsworthy, and R. Webb. 2005. Effects of dietary carbohydrate source on oocyte/ embryo quality and development in high-yielding, lactating dairy cattle. Biol. Reprod. 2005:135-136. 
Friedman, E., H. Voet, D. Reznikov, D. Wolfenson, and Z. Roth. 2014. Hormonal treatment before and after artificial insemination differentially improves fertility in subpopulations of dairy cows during the summer and autumn. J. Dairy Sci. 97:7465-7475.

Garcia-Ispierto, I., A. Abdelfatah, and F. Lopez-Gatius. 2013. Melatonin treatment at dry-off improves reproductive performance postpartum in high-producing dairy cows under heat stress conditions. Reprod. Domest. Anim. 48:577-583.

Garner, J. B., M. L. Douglas, S. R. Williams, W. J. Wales, L. C. Marett, T. T. Nguyen, C. M. Reich, and B. J. Hayes. 2016. Genomic selection improves heat tolerance in dairy cattle. Sci. Rep. 6:34114

Garnsworthy, P. C., A. A. Fouladi-Nashta, G. E. Mann, K. D. Sinclair, and R. Webb. 2009. Effect of dietary-induced changes in plasma insulin concentrations during the early post partum period on pregnancy rate in dairy cows. Reproduction 137:759-768.

Gebremedhin, K. G., B. Wu, and K. Perano. 2016. Modeling conductive cooling for thermally stressed dairy cows. J. Therm. Biol. 56:91-99.

Girard, C. L., and J. J. Matte. 1998. Dietary supplements of folic acid during lactation: Effects on the performance of dairy cows. J. Dairy Sci. 81:1412-1419.

Girard, C. L., J. J. Matte, and G. F. Tremblay. 1989. Serum folates in gestating and lactating dairy cows. J. Dairy Sci. 72:3240-3246.

Girard, C. L., J. J. Matte, and G. F. Tremblay. 1995. Gestation and lactation of dairy cows: A role for folic acid? J. Dairy Sci. 78:404411.

Gong, J. G., W. J. Lee, P. C. Garnsworthy, and R. Webb. 2002. Effect of dietary-induced increases in circulating insulin concentrations during the early postpartum period on reproductive function in dairy cows. Reproduction 123:419-427.

Guo, J., S. Gao, S. Quan, Y. Zhang, D. Bu, and J. Wang. 2018. Blood amino acids profile responding to heat stress in dairy cows. AsianAustralas. J. Anim. Sci. 31:47-53.

Gursu, M. F., M. Onderci, F. Gulcu, and K. Sahin. 2004. Effects of vitamin $\mathrm{C}$ and folic acid supplementation on serum paraoxonase activity and metabolites induced by heat stress in vivo. Nutr. Res. 24:157-164.

Hall, G. M., J. N. Lucke, R. Lovell, and D. Lister. 1980. Porcine malignant hyperthermia. VII: Hepatic metabolism. Br. J. Anaesth. $52: 11-17$.

Hall, L. W., F. R. Dunshea, J. D. Allen, S. Rungruang, J. L. Collier, N. M. Long, and R. J. Collier. 2016. Evaluation of dietary betaine in lactating Holstein cows subjected to heat stress. J. Dairy Sci. 99:9745-9753.

Han, Z., G. Zhou, Z. Jin, G. Wang, and H. Li. 2009. Effects of rumen protected methionine on performance, apoptosis of lymphocytes and related genes in dairy cows under heat stress. Chin. J. Anim. Nutr. 21:665-672.

Hansen, P. J., and C. F. Arechiga. 1999. Strategies for managing reproduction in the heat-stressed dairy cow. J. Anim. Sci. 77(Suppl. 2):36-50.

Hulme, M. 1997. Global warming. Prog. Phys. Geogr. 21:446-453.

Hunter, R. H. F., F. Lopez-Gatius, and O. Lopez-Albors. 2017. Temperature gradients in vivo influence maturing male and female gametes in mammals: Evidence from the cow. Reprod. Fertil. Dev. 29:2301-2304.

Ikeda, S., T. Namekawa, M. Sugimoto, and S. Kume. 2010. Expression of methylation pathway enzymes in bovine oocytes and preimplantation embryos. J. Exp. Zool. A Ecol. Genet. Physiol. 313:129-136.

Jimenez-Caban, E., A. Riera Blanco, and M. Pagan-Morales. 2015. Correlation of hair length and width with genetic potential for production traits in Puerto Rican Holstein cattle. J. Agr. U. Puerto Rico 99:13-18.

Kekana, T. W., F. V. Nherera-Chokuda, M. C. Muya, K. M. Manyama, and K. C. Lehloenya. 2018. Milk production and blood metabolites of dairy cattle as influenced by thermal-humidity index. Trop. Anim. Health Prod. 50:921-924.

Kim, E. S., J. S. Seo, J. H. Eum, J. E. Lim, D. H. Kim, T. K. Yoon, and D. R. Lee. 2009. The effect of folic acid on in vitro maturation and subsequent embryonic development of porcine immature oocytes. Mol. Reprod. Dev. 76:120-121.
Koyama, H., S. Ikeda, M. Sugimoto, and S. Kume. 2012. Effects of folic acid on the development and oxidative stress of mouse embryos exposed to heat stress. Reprod. Domest. Anim. 47:921-927.

Krininger, C. E., III, S. H. Stephens, and P. J. Hansen. 2002. Developmental changes in inhibitory effects of arsenic and heat shock on growth of pre-implantation bovine embryos. Mol. Reprod. Dev. 63:335-340.

Kwong, W. Y., S. J. Adamiak, A. Gwynn, R. Singh, and K. D. Sinclair. 2010. Endogenous folates and single-carbon metabolism in the ovarian follicle, oocyte and pre-implantation embryo. Reproduction 139:705-715.

Lamp, O., M. Derno, W. Otten, M. Mielenz, G. Nurnberg, and B. Kuhla. 2015. Metabolic heat stress adaption in transition cows: Differences in macronutrient oxidation between late-gestating and earlylactating German Holstein dairy cows. PLoS One 10:e0125264.

Lan, R., and I. Kim. 2018. Effects of feeding diets containing essential oils and betaine to heat-stressed growing-finishing pigs. Arch Anim. Nutr. 72:368-378.

Landaeta-Hernández, A., S. Zambrano-Nava, J. P. Hernández-Fonseca, R. Godoy, M. Calles, J. L. Iragorri, L. Anez, M. Polanco, M. Montero-Urdaneta, and T. Olson. 2011. Variability of hair coat and skin traits as related to adaptation in Criollo Limonero cattle. Trop. Anim. Health Prod. 43:657-663.

Lawrence, B. V., A. P. Schinckel, O. Adeola, and K. Cera. 2002. Impact of betaine on pig finishing performance and carcass composition. J. Anim. Sci. 80:475-482.

Lawrence, J. L., R. R. Payton, J. D. Godkin, A. M. Saxton, F. N. Schrick, and J. L. Edwards. 2004. Retinol improves development of bovine oocytes compromised by heat stress during maturation. J. Dairy Sci. 87:2449-2454.

Leiva, T., R. F. Cooke, A. P. Brandao, U. Pardelli, R. O. Rodrigues, F. N. Corra, and J. L. Vasconcelos. 2017. Effects of concentrate type and chromium propionate on insulin sensitivity, productive and reproductive parameters of lactating dairy cows consuming excessive energy. Animal 11:436-444.

Lewis, G. S., W. W. Thatcher, E. L. Bliss, M. Drost, and R. J. Collier. 1984. Effects of heat stress during pregnancy on postpartum reproductive changes in Holstein cows. J. Anim. Sci. 58:174-186.

López-Gatius, F., and R. Hunter. 2017. Clinical relevance of pre-ovulatory follicular temperature in heat-stressed lactating dairy cows. Reprod. Domest. Anim. 52:366-370.

López-Gatius, F., and R. H. F. Hunter. 2019. Pre-ovulatory follicular cooling correlates positively with the potential for pregnancy in dairy cows: Implications for human IVF. J. Gynecol. Obstet. Hum. Reprod.48:419-422.

Lucio, A. C., B. G. Alves, K. A. Alves, M. C. Martins, L. S. Braga, L. Miglio, B. G. Alves, T. H. Silva, J. O. Jacomini, and M. E. Beletti. 2016. Selected sperm traits are simultaneously altered after scrotal heat stress and play specific roles in in vitro fertilization and embryonic development. Theriogenology 86:924-933.

Lussier, J. G., P. Matton, and J. J. Dufour. 1987. Growth rates of follicles in the ovary of the cow. J. Reprod. Fertil. 81:301-307.

Malama, E., Y. Zeron, F. Janett, M. Siuda, Z. Roth, and H. Bollwein. 2017. Use of computer-assisted sperm analysis and flow cytometry to detect seasonal variations of bovine semen quality. Theriogenology 87:79-90.

Mallonée, P. G., D. K. Beede, R. J. Collier, and C. J. Wilcox. 1985. Production and physiological responses of dairy cows to varying dietary potassium during heat stress. J. Dairy Sci. 68:1479-1487.

Mariasegaram, M., C. C. Chase Jr., J. X. Chaparro, T. A. Olson, R. A. Brenneman, and R. P. Niedz. 2007. The slick hair coat locus maps to chromosome 20 in Senepol-derived cattle. Anim. Genet. 38:54-59.

Martins, J. M., J. A. Neves, A. Freitas, and J. L. Tirapicos. 2012. Effect of long-term betaine supplementation on chemical and physical characteristics of three muscles from the Alentejano pig. J. Sci. Food Agric. 92:2122-2127.

Maya-Soriano, M. J., F. Lopez-Gatius, C. Andreu-Vazquez, and M. Lopez-Bejar. 2013. Bovine oocytes show a higher tolerance to heat shock in the warm compared with the cold season of the year. Theriogenology 79:299-305. 
Mendoza, S. M., E. van Heugten, R. D. Boyd, and P. R. Ferket. 2017. Effects of dietary supplementation of the osmolyte betaine on growing pig performance and serological and hematological indices during thermoneutral and heat-stressed conditions1. J. Anim. Sci. 95:5040-5053.

Min, L., J. Cheng, S. Zhao, H. Tian, Y. Zhang, S. Li, H. Yang, N. Zheng, and J. Wang. 2016. Plasma-based proteomics reveals immune response, complement and coagulation cascades pathway shifts in heat-stressed lactating dairy cows. J. Proteomics 146:99108.

Min, L., J. B. Cheng, B. L. Shi, H. J. Yang, N. Zheng, and J. Q. Wang. 2015. Effects of heat stress on serum insulin, adipokines, AMPactivated protein kinase, and heat shock signal molecules in dairy cows. J. Zhejiang Univ. Sci. B 16:541-548.

Moghaddam, A., I. Karimi, and M. Pooyanmehr. 2009. Effects of short-term cooling on pregnancy rate of dairy heifers under summer heat stress. Vet. Res. Commun. 33:567-575.

Moonsie-Shageer, S., and D. N. Mowat. 1993. Effect of level of supplemental chromium on performance, serum constituents, and immune status of stressed feeder calves. J. Anim. Sci. 71:232-238.

Nguyen, T. T. T., P. J. Bowman, M. Haile-Mariam, J. E. Pryce, and B. J. Hayes. 2016. Genomic selection for tolerance to heat stress in Australian dairy cattle. J. Dairy Sci. 99:2849-2862.

Nikkhah, A., D. Kianzad, A. Hajhosseini, and A. Zalbeyk. 2013. Protected methionine prolonged provision improves summer production and reproduction of lactating dairy cows. Pak J Biol Sci. $16: 558-563$.

Raheja, N., N. Kumar, B. Patel, and S. S. Lathwal. 2018. Effect of dietary betaine on reproductive performance of Karan Fries cows during hot humid season. Int. J. Curr. Microbiol. Appl. Sci. 7:1451-1460.

Niu, M., and K. J. Harvatine. 2018. Short communication: The effects of morning compared with evening feed delivery in lactating dairy cows during the summer. J. Dairy Sci. 101:396-400.

O'Brien, M. D., R. P. Rhoads, S. R. Sanders, G. C. Duff, and L. H. Baumgard. 2010. Metabolic adaptations to heat stress in growing cattle. Domest. Anim. Endocrinol. 38:86-94.

Olson, T. A., C. Lucena, C. C. Chase Jr., and A. C. Hammond. 2003. Evidence of a major gene influencing hair length and heat tolerance in Bos taurus cattle. J. Anim. Sci. 81:80-90.

Ortega, M. S., N. A. S. Rocha-Frigoni, G. Z. Mingoti, Z. Roth, and P. J. Hansen. 2016. Modification of embryonic resistance to heat shock in cattle by melatonin and genetic variation in HSPA1L. J. Dairy Sci. 99:9152-9164.

Ortiz, X. A., J. F. Smith, F. Rojano, C. Y. Choi, J. Bruer, T. Steele, N. Schuring, J. Allen, and R. J. Collier. 2015. Evaluation of conductive cooling of lactating dairy cows under controlled environmental conditions. J. Dairy Sci. 98:1759-1771.

Ou, X. H., S. Li, Z. B. Wang, M. Li, S. Quan, F. Xing, L. Guo, S B. Chao, Z. Chen, X. W. Liang, Y. Hou, H. Schatten, and Q. Y. Sun. 2012. Maternal insulin resistance causes oxidative stress and mitochondrial dysfunction in mouse oocytes. Hum. Reprod. 27:2130-2145.

Patiño Chaparro, J. M. 2016. Comparison of genetic variations related to productive efficiency of Slick Holstein cattle versus non-Slick. Master's thesis. University of Puerto Rico, Mayaguez Campus.

Payton, R. R., L. A. Rispoli, K. A. Nagle, C. Gondro, A. M. Saxton, B. H. Voy, and J. L. Edwards. 2018. Mitochondrial-related consequences of heat stress exposure during bovine oocyte maturation persist in early embryo development. J. Reprod. Dev. 64:243-251.

Pegorer, M. F., J. L. Vasconcelos, L. A. Trinca, P. J. Hansen, and C. M. Barros. 2007. Influence of sire and sire breed (Gyr versus Holstein) on establishment of pregnancy and embryonic loss in lactating Holstein cows during summer heat stress. Theriogenology 67:692-697.

Perano, K. M., J. G. Usack, L. T. Angenent, and K. G. Gebremedhin. 2015. Production and physiological responses of heat-stressed lactating dairy cattle to conductive cooling. J. Dairy Sci. 98:52525261.

Pereira, M. H., A. D. Rodrigues, T. Martins, W. V. Oliveira, P. S. Silveira, M. C. Wiltbank, and J. L. Vasconcelos. 2013. Timed arti- ficial insemination programs during the summer in lactating dairy cows: Comparison of the 5-d Cosynch protocol with an estrogen/ progesterone-based protocol. J. Dairy Sci. 96:6904-6914.

Perez-Miguelsanz, J., N. Vallecillo, F. Garrido, E. Reytor, D. PerezSala, and M. A. Pajares. 2017. Betaine homocysteine S-methyltransferase emerges as a new player of the nuclear methionine cycle. Biochim. Biophys. Acta Mol. Cell Res. 1864:1165-1182.

Pinedo, P. J., and A. De Vries. 2017. Season of conception is associated with future survival, fertility, and milk yield of Holstein cows. J. Dairy Sci. 100:6631-6639.

Polsky, L. B. A. M. L. Madureira, E. L. D. Filho, S. Soriano, A. F. Sica, J. L. M. Vasconcelos, and R. L. A. Cerri. 2017. Association between ambient temperature and humidity, vaginal temperature, and automatic activity monitoring on induced estrus in lactating cows. J. Dairy Sci. 100:8590-8601.

Putney, D. J., M. Drost, and W. W. Thatcher. 1989. Influence of summer heat stress on pregnancy rates of lactating dairy cattle following embryo transfer or artificial insemination. Theriogenology $31: 765-778$.

Putney, D. J., J. R. Malayer, T. S. Gross, W. W. Thatcher, P. J. Hansen, and M. Drost. 1988. Heat stress-induced alterations in the synthesis and secretion of proteins and prostaglandins by cultured bovine conceptuses and uterine endometrium. Biol. Reprod. 39:717-728.

Qiao, J., and H. L. Feng. 2011. Extra- and intra-ovarian factors in polycystic ovary syndrome: Impact on oocyte maturation and embryo developmental competence. Hum. Reprod. Update 17:17-33.

Rahman, M. B., K. Schellander, N. L. Luceno, and A. Van Soom. 2018. Heat stress responses in spermatozoa: Mechanisms and consequences for cattle fertility. Theriogenology 113:102-112.

Rahman, M. B., L. Vandaele, T. Rijsselaere, D. Maes, M. Hoogewijs, A. Frijters, J. Noordman, A. Granados, E. Dernelle, M. Shamsuddin, J. J. Parrish, and A. Van Soom. 2011. Scrotal insulation and its relationship to abnormal morphology, chromatin protamination and nuclear shape of spermatozoa in Holstein-Friesian and Belgian Blue bulls. Theriogenology 76:1246-1257.

Rhoads, M. L., R. P. Rhoads, M. J. VanBaale, R. J. Collier, S. R. Sanders, W. J. Weber, B. A. Crooker, and L. H. Baumgard. 2009. Effects of heat stress and plane of nutrition on lactating Holstein cows: I. Production, metabolism, and aspects of circulating somatotropin. J. Dairy Sci. 92:1986-1997.

Riley, D. G., C. C. Chase, S. W. Coleman, and T. A. Olson. 2012. Genetic assessment of rectal temperature and coat score in Brahman, Angus, and Romosinuano crossbred and straightbred cows and calves under subtropical summer conditions. Livest. Sci 148:109-118

Rius, A. G., J. Kaufman, K. Kassube, and K. G. Pohler. 2016. The effect of heat stress and jugular infusions of methionine, lysine, and branched-chain amino acids in lactating dairy cattle. J. Anim. Sci. 94(Suppl_5):772-773.

Roth, Z., A. Arav, A. Bor, Y. Zeron, R. Braw-Tal, and D. Wolfenson. 2001. Improvement of quality of oocytes collected in the autumn by enhanced removal of impaired follicles from previously heatstressed cows. Reproduction 122:737-744.

Roth, Z., and P. J. Hansen. 2004. Involvement of apoptosis in disruption of developmental competence of bovine oocytes by heat shock during maturation. Biol. Reprod. 71:1898-1906.

Roth, Z., and P. J. Hansen. 2005. Disruption of nuclear maturation and rearrangement of cytoskeletal elements in bovine oocytes exposed to heat shock during maturation. Reproduction 129:235-244.

Roth, Z., and D. Wolfenson. 2016. Comparing the effects of heat stress and mastitis on ovarian function in lactating cows: basic and applied aspects. Domest. Anim. Endocrinol. 56(Suppl.):S218-S227.

Roush, W. 1994. Population-The view from Cairo. Science 265:11641167.

Sabés-Alsina, M., A. Johannisson, N. Lundeheim, M. Lopez-Bejar, and J. M. Morrell. 2017. Effects of season on bull sperm quality in thawed samples in northern Spain. Vet. Rec. 180:251.

Sakatani, M. 2017. Effects of heat stress on bovine preimplantation embryos produced in vitro. J. Reprod. Dev. 63:347-352. 
Sakatani, M., S. Kobayashi, and M. Takahashi. 2004. Effects of heat shock on in vitro development and intracellular oxidative state of bovine preimplantation embryos. Mol. Reprod. Dev. 67:77-82.

Sartori, R., R. Sartor-Bergfelt, S. A. Mertens, J. N. Guenther, J. J. Parrish, and M. C. Wiltbank. 2002. Fertilization and early embryonic development in heifers and lactating cows in summer and lactating and dry cows in winter. J. Dairy Sci. 85:2803-2812.

Satrapa, R. A., T. Nabhan, C. F. Silva, R. A. Simoes, E. M. Razza, R. Z. Puelker, L. A. Trinca, and C. M. Barros. 2011. Influence of sire breed (Bos indicus versus Bos taurus) and interval from slaughter to oocyte aspiration on heat stress tolerance of in vitro-produced bovine embryos. Theriogenology 76:1162-1167.

Schüller, L. K., O. Burfeind, and W. Heuwieser. 2014. Impact of heat stress on conception rate of dairy cows in the moderate climate considering different temperature-humidity index thresholds, periods relative to breeding, and heat load indices. Theriogenology 81:1050-1057.

Schüller, L. K., I. Michaelis, and W. Heuwieser. 2017. Impact of heat stress on estrus expression and follicle size in estrus under field conditions in dairy cows. Theriogenology 102:48-53.

Senesi, P., L. Luzi, A. Montesano, N. Mazzocchi, and I. Terruzzi. 2013. Betaine supplement enhances skeletal muscle differentiation in murine myoblasts via IGF-1 signaling activation. J. Transl. Med. $11: 174$.

Shin, J.-H., and K. Shiota. 1999. Folic acid supplementation of pregnant mice suppresses heat-induced neural tube defects in the offspring. J. Nutr. 129:2070-2073.

Silva, C. F., E. S. Sartorelli, A. C. Castilho, R. A. Satrapa, R. Z. Puelker, E. M. Razza, J. S. Ticianelli, H. P. Eduardo, B. Loureiro, and C. M. Barros. 2013. Effects of heat stress on development, quality and survival of Bos indicus and Bos taurus embryos produced in vitro. Theriogenology 79:351-357.

Sinclair, K. D., C. Allegrucci, R. Singh, D. S. Gardner, S. Sebastian, J. Bispham, A. Thurston, J. F. Huntley, W. D. Rees, C. A. Maloney, R. G. Lea, J. Craigon, T. G. McEvoy, and L. E. Young. 2007. DNA methylation, insulin resistance, and blood pressure in offspring determined by maternal periconceptional $\mathrm{B}$ vitamin and methionine status. Proc. Natl. Acad. Sci. USA 104:19351-19356.

Skibiel, A. L., F. Peñagaricano, R. Amorín, B. M. Ahmed, G. E. Dahl, and J. Laporta. 2018. In utero heat stress alters the offspring epigenome. Sci. Rep. 8:14609.

Soltan, M. A. 2010. Effect of dietary chromium supplementation on productive and reproductive performance of early lactating dairy cows under heat stress. J. Anim. Physiol. Anim. Nutr. (Berl.) 94:264-272.

Spiers, D. E., J. N. Spain, M. R. Ellersieck, and M. C. Lucy. 2018. Strategic application of convective cooling to maximize the thermal gradient and reduce heat stress response in dairy cows. J. Dairy Sci. 101:8269-8283.

St-Pierre, N. R., B. Cobanov, and G. Schnitkey. 2003. Economic losses from heat stress by US livestock industries. J. Dairy Sci. 86:E52E77.

Stover, P. J. 2009. One-carbon metabolism-genome interactions in folate-associated pathologies. J. Nutr. 139:2402-2405.

Tao, S., and G. E. Dahl. 2013. Invited review: Heat stress effects during late gestation on dry cows and their calves. J. Dairy Sci. 96:4079-4093

Tao, S., A. P. Monteiro, M. J. Hayen, and G. E. Dahl. 2014. Short communication: Maternal heat stress during the dry period alters postnatal whole-body insulin response of calves. J. Dairy Sci. 97:897-901.
Torlińska, T., R. Banach, J. Paluszak, and A. Gryczka-Dziadecka. 1987. Hyperthermia effect on lipolytic processes in rat blood and adipose tissue. Acta Physiol. Pol. 38:361-366.

Turk, R., O. Podpecan, J. Mrkun, Z. Flegar-Mestric, S. Perkov, and P. Zrimsek. 2015. The effect of seasonal thermal stress on lipid mobilisation, antioxidant status and reproductive performance in dairy cows. Reprod. Domest. Anim. 50:595-603.

Ullah, G., J. W. Fuquay, T. Keawkhong, B. L. Clark, D. E. Poque, and E. J. Murphey. 1996. Effect of gonadotropin-releasing hormone at estrus on subsequent luteal function and fertility in lactating Holsteins during heat stress. J. Dairy Sci. 79:1950-1953.

van der Molen, E. F., L. P. van den Heuvel, M. T. te Poele Pothoff, I. A. Monnens, T. K. Eskes, and H. J. Blom. 1996. The effect of folic acid on the homocysteine metabolism in human umbilical vein endothelial cells (HUVECs). Eur. J. Clin. Invest. 26:304-309.

Voelz, B. E., L. Rocha, F. Scortegagna, J. S. Stevenson, and L. G. D Mendonca. 2016. Treatment of lactating dairy cows with gonadotropin-releasing hormone before first insemination during summer heat stress. J. Dairy Sci. 99:7612-7623.

Wang, J. P., D. P. Bu, J. Q. Wang, X. K. Huo, T. J. Guo, H. Y. Wei, L. Y. Zhou, R. R. Rastani, L. H. Baumgard, and F. D. Li. 2010. Effect of saturated fatty acid supplementation on production and metabolism indices in heat-stressed mid-lactation dairy cows. J. Dairy Sci. 93:4121-4127.

Wang, J. Z., H. S. Sui, D. Q. Miao, N. Liu, P. Zhou, L. Ge, and J. H. Tan. 2009. Effects of heat stress during in vitro maturation on cytoplasmic versus nuclear components of mouse oocytes. Reproduction 137:181-189.

West, J. W. 1999. Nutritional strategies for managing the heat-stressed dairy cow. J. Anim. Sci. 77(Suppl. 2):21-35.

West, J. W. 2003. Effects of heat-stress on production in dairy cattle. J. Dairy Sci. 86:2131-2144.

Wheelock, J. B., R. P. Rhoads, M. J. Vanbaale, S. R. Sanders, and L. H. Baumgard. 2010. Effects of heat stress on energetic metabolism in lactating Holstein cows. J. Dairy Sci. 93:644-655.

Wilson, S. J., R. S. Marion, J. N. Spain, D. E. Spiers, D. H. Keisler, and M. C. Lucy. 1998. Effects of controlled heat stress on ovarian function of dairy cattle. 1. Lactating cows. J. Dairy Sci. 81:21242131

Wolfenson, D., I. Flamenbaum, and A. Berman. 1988. Dry period heat stress relief effects on prepartum progesterone, calf birth weight, and milk production. J. Dairy Sci. 71:809-818.

Wolfenson, D., B. J. Lew, W. W. Thatcher, Y. Graber, and R. Meidan. 1997. Seasonal and acute heat stress effects on steroid production by dominant follicles in cows. Anim. Reprod. Sci. 47:9-19.

Zhang, F. J., X. G. Weng, J. F. Wang, D. Zhou, W. Zhang, C. C. Zhai, Y. X. Hou, and Y. H. Zhu. 2014a. Effects of temperature-humidity index and chromium supplementation on antioxidant capacity, heat shock protein 72 , and cytokine responses of lactating cows. J. Anim. Sci. 92:3026-3034.

Zhang, L., S. J. Ying, W. J. An, H. Lian, G. B. Zhou, and Z. Y. Han. 2014b. Effects of dietary betaine supplementation subjected to heat stress on milk performances and physiology indices in dairy cow. Genetics and molecular research. Genet. Mol. Res. 13:7577-7586.

Zhou, Z., M. Vailati-Riboni, E. Trevisi, J. K. Drackley, D. N. Luchini, and J. J. Loor. 2016. Better postpartal performance in dairy cows supplemented with rumen-protected methionine compared with choline during the peripartal period. J. Dairy Sci. 99:8716-8732. 